\title{
The environmental impacts of 2019 oil spill on the Brazilian coast: Overview
}

\section{Geonildo Rodrigo Disner ${ }^{1}$ and Mariana Torres ${ }^{2}$}

\author{
${ }^{1}$ Butantan Institute. Laboratory of Applied Toxinology. Av. Vital Brasil, 1500. São \\ Paulo-SP, Brazil (CEP 05503-900). Email: disner.rodrigo@gmail.com. \\ ${ }^{2}$ University of São Paulo. School of Pharmaceutical Sciences. Postgraduate Program \\ of Pathophysiology and Toxicology. Av. Professor Lineu Prestes, 580, Bloco 13A, \\ térreo. São Paulo-SP, Brasil (CEP 05508-000).
}

\begin{abstract}
The oil spill off the Brazilian coast, which reached especially the Northeast in 2019, is known as the biggest disaster of its kind in the country's history. Accidents of this type are not new; however, this episode had enormous proportions with 11 states, 130 municipalities, and more than 1,000 locations affected by oil stains or residues. Considering the extent of this environmental tragedy associated with the Brazilian biodiversity peculiarities is immeasurable the damages to fauna and protected areas, especially those that are more sensitive, such as mangroves and coral reefs. It is known that the oil source is Venezuela, but those responsible for the disaster are not known yet. The neglect in investigating events and decision making to deal with the incident aggravated the effects on habitats and local communities. The first occurrence on the coast happened on August 30, 2019, and the most significant number of affected locations was recorded during November. However, even without a complete solution of the case, in January 2020, the monitoring and evaluation group responsible for monitoring, remediation, and protection actions, officially announce the beginning of the demobilization protocol, establishing the termination points, which represent the end of monitoring in most of the areas. Contradictorily, in some locations considered sensitive, the end of the work will be carried out "even with the significant presence of oil in the area". Studies in the literature indicate that highly weathered oil, which has a high molecular weight and low solubility PAHs, can have toxic effects as representative or higher than its non-weathered counterpart. These findings contradict a classic paradigm that crude oil with low molecular weight and more volatile PAHs are primarily responsible for toxicity. Regardless of the damages caused by the activities of total oil removal compared to natural degradation, there is a disregard for this issue, a deficit of environmental agencies employees and investments in this sector. Given the initiative to demobilize activities related to this serious accident, this review seeks to contextualize similar accidents, synthesize the events, dimensions, and environmental consequences related to the most significant ecological disaster on the Brazilian coast and discuss

Received

Mar. 23, 2020

Accepted

Apr. 28, 2020

Release

Apr. 30, 2020

Open access

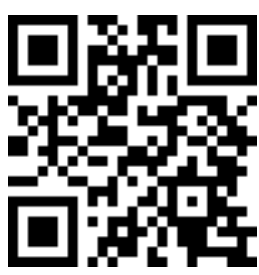

ORCID

(1) 0000-0002-4561-1361 Geonildo Rodrigo Disner

(D) $0000-0003-3136-1952$ Mariana Torres
\end{abstract}


its likely environmental impacts considering the physicalchemical characteristics of the pollutant. In recent years, Brazil has been the scene of unprecedented disasters. The oil in the Northeast, along with the Mariana and Brumadinho dam rupture and the fires in the Amazon shows the lack of critical assessment of the environmental issue in Brazil, and what appears to be a society plan that, through structural measures, allows cases of environmental degradation to happen with impunity and the conservation of natural resources is genuinely not a priority of government actions.

Keywords: Petroleum; Weathered oil; PAHs; Environmental contamination; Environmental monitoring.

Resumo. Impactos ambientais do derramamento de petróleo de 2019 na costa brasileira: revisão. 0 derramamento de óleo na costa do Brasil, que atingiu especialmente o Nordeste, no ano de 2019, ficou conhecido como o maior desastre dessa natureza na história do país. Acidentes deste tipo não são inéditos, no entanto, esse episódio apresentou enorme proporção onde 11 estados, 130 municípios e mais de 1000 localidades foram atingidas por manchas ou resíduos de óleo. Considerando a extensão desse desastre ambiental associado às peculiaridades da biodiversidade brasileira, calcula-se um inestimável prejuízo à fauna e às áreas de proteção, especialmente aquelas mais sensíveis, como mangues e recifes de corais. Sabe-se que o óleo possui origem venezuelana, porém não são conhecidos ainda os responsáveis pelo desastre. As negligências na apuração dos eventos e na tomada de ações para o enfrentamento do incidente agravaram ainda mais os efeitos sobre os habitats e comunidades locais. A primeira ocorrência no litoral deu-se em 30 de agosto de 2019 e o mês de novembro foi quando o maior número de localidades afetadas foi registrado. No entanto, mesmo sem uma completa solução do caso, em janeiro de 2020 o grupo de acompanhamento e avaliação, responsável pelo monitoramento e ações de remediação e proteção ambiental, divulgaram oficialmente o início da desmobilização relacionada ao acidente, estabelecendo os pontos de término que representam a parada de monitoramento na maioria das áreas. Contraditoriamente, em alguns pontos considerados sensíveis, o fim dos trabalhos será realizado "mesmo com a presença expressiva de óleo na área". Estudos na literatura apontam que o óleo intemperizado é composto por substâncias de alto peso molecular (como HPAs de baixa solubilidade), os quais podem provocar efeitos tóxicos tão representativos ou maiores que sua contraparte não-intemperizada. Estes achados violam um paradigma clássico de que o óleo cru com baixo peso molecular e HPAs mais voláteis sejam os principais responsáveis pela toxicidade. Independente dos prejuízos causados pelas atividades de remoção total do óleo comparados à degradação natural, percebe-se um descaso com este assunto, um déficit de funcionários das agências ambientais e investimentos neste setor. Frente à iniciativa de desmobilização 
das atividades relacionadas a este grave acidente, esta revisão busca contextualizar incidentes similares, sintetizar os eventos, dimensões e consequências ambientais relacionadas ao maior desastre ambiental da costa brasileira e discutir as suas possíveis consequências ambientais considerando as características físicas e químicas do poluente. Nos últimos anos o Brasil tem sido cenário de desastres ambientais sem precedentes. 0 óleo no Nordeste, juntamente com o rompimento das barragens de Mariana e Brumadinho e os incêndios na Amazônia, carecem de uma avaliação crítica sobre a questão ambiental no Brasil, e do que parece ser um plano de sociedade que através de medidas estruturais permitem que os casos de degradação ambiental aconteçam impunemente e a conservação dos recursos naturais não seja considerada uma prioridade das ações governamentais.

Palavras-chave: Petróleo; Óleo intemperizado; HPAs; Contaminação ambiental; Monitoramento ambiental.

\section{Introduction}

A significant amount of oil is continuously released into the oceans, both from natural and anthropogenic sources (US National Academy of Science, 2004). These episodes might occur during natural seeps, accidental spills, field exploration and transportation, maritime traffic, ship-to-ship (STS) transfer operations, and refinery effluent discharge. Eventual impactful accidents happen to spotlight this activity, which has, on the one hand, a significant influence on economy and development but also, on the other hand, is quite polluting, raising the concern on the environmental awareness and protection of marine and shore communities.

The Deepwater Horizon (DWH) oil spill was the most emblematic and largest marine incident in history. It occurred from April 20 to July 14 in 2010, releasing around 5 million barrels of oil and gas into the Gulf of Mexico (Magnuson et al., 2018). Along with DWH, the 1989 Exxon Valdez oil outpour in Alaska spilled 10.8 million US gallons $(37,000$ metric tons) of crude oil, and it is considered to be one of the worst human-caused environmental disasters and the most massive oil spill in U.S. waters (US National Academy of Science, 2004).

In the Brazilian context, it is worth mention some examples of mishaps regarding oil and derivatives disasters. In 1984, a failure in Petrobras underground pipelines released 700,000 liters of gasoline around the Socó village, located in Cubatão (São Paulo state). After the leak, a fire destroyed part of a local community, causing nearly 100 deaths (Sindipetro-LP, 2019). Before this accident (in the 1980s), Cubatão has been pointed by the United Nations as the most polluted city in the world and became globally known as "The Death Valley" (Costa and Gomes, 2017). Besides that, in 2000, an accident with an oil tanker resulted in more than one million liters of oil in the Guanabara Bay, Rio de Janeiro state. It was registered the death of local fauna and soil pollution in several municipalities nearby. Likewise, in 2011, the American company Chevron has dumped about 3,000 barrels of oil into the sea in Campos Basin, also in Rio de Janeiro, causing a 160-mile-long stain and plenty of animal deaths (Gonçalves, 2017).

Since July 2019, the Brazilian coast and the entire country have faced what is unanimous among specialists: one of the biggest environmental disasters in history. Delayed responses of the competent authorities in monitoring and decision making let the spill became one of the most serious in the world and undoubtedly the worse in the 
history of Brazilian shore (Fioravanti, 2020). Months after the first registered occurrence, the oil origin remains unknown, and the scenario is marked with uncertainties.

Initially, the Brazilian Institute for the Environment and Natural Resources (IBAMA) and the local communities focused on removing the supernatant layer of dense oil in the water, sand, and rocks, as well as promptly assist the affected fauna. However, since January 2020, the plan to demobilize monitoring activities has started, assuming that once removed, the oil will not have any effect on the affected ecosystems. According to information from the institute, this oil is dense, highly weathered, which makes it persistent. As its density is close to seawater, it can sink, mixing with sand and other materials. In addition to the risk of suffocating animals, the risk of solubilization of some compounds in water cannot be ruled out, which, even at low concentrations, can be toxic to aquatic organisms (Galvan et al., 2016; US National Academy of Science, 2004).

Thus, this study aims to report the main events of the most significant environmental oil accident in Brazil and to contextualize its dimensions. Furthermore, show and discuss previous works that can support the risk prediction associated with chemical compounds even after the removal of crude oil, and the medium to long-term impact in natural environments and exposed organisms. In addition, this overview might have a greater reach in and outside Brazil to raise awareness about the current national environmental crises and push the authorities to respond with adequate procedures and investigations.

\section{Accident events and dimensions}

The 2019 remarkable oil spill on the Brazilian coast is known as the most extensive environmental disaster of its kind ever registered in the country. The first oil spot appeared on the beaches of Jacumã and Tambaba, in the Municipality of Conde, Paraíba on August 30, 2019 (Figure 1).

What appeared to be a localized incident became broader over the next few days, raising social concern and high media coverage (BBC News, 2019; Madeiro, 2019; The Guardian, 2019). By the second week, five Northeast states had oil records. On the next week, the spots were concentrated on the vast amount in the state of Rio Grande do Norte, carried by the waters of the region's sea currents. By the fourth week, the spots were already in eight states of the Northeast and within the fifth week, reached all the nine states of the region, when the municipality of Conde, state of Bahia, had been affected (Soares et al., 2020; Dantas et al., 2019; IBAMA, 2019a). In the Southeast region, the first spot has appeared on Guriri beach, at São Mateus coast, in the north of Espírito Santo, on November 7. In Rio de Janeiro, oil fragments reached Grussaí Beach in São João da Barra on November 22, and analyzes confirmed that it was the same material as the beaches of the Northeast (Figure 1) (IBAMA, 2019a).

Right after the occurrence of the first spots, there was significant involvement of local communities in helping to remove the oil from the beaches. There were even reports of intoxication of these volunteers after exposure to oil since most of them did not use any safety equipment (Dantas and Manzano, 2019; Pitombo and Valadares, 2019). Even so, the Ministry of Health and the Navy issued just on October 24 a recommendation for the population to avoid direct contact with the substance spread along the beaches, which might contain carcinogenic substances (Secretaria de Vigilância em Saúde, 2019).

On October 25, the government announced the creation of a website containing informations on the emergence of spots (IBAMA, 2019b). Just at this point, specific details on affected locations and fauna got public. 


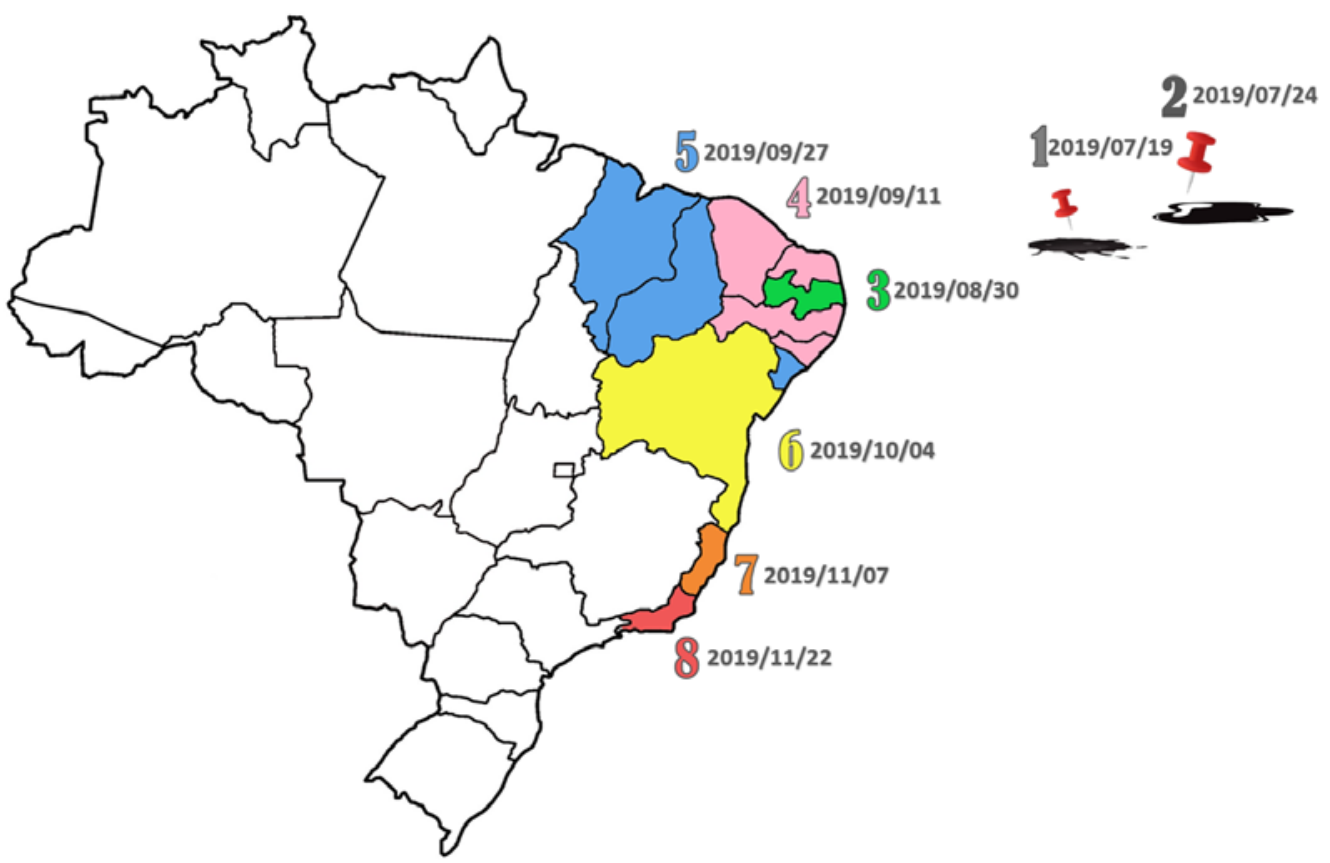

Figure 1. Timeline concerning the major events since the detection by satellite images of oil spills offshore and its advance over the Brazilian coast. 1) Sentinel-1A satellite detected a large oil stain $26 \mathrm{~km}$ off the northeast coast. 2) Sentinel-1A satellite registered another large oil stain $40 \mathrm{~km}$ off the coast. 3) First oil spot on Jacumã and Tambaba beaches at Conde/Paraíba. 4) Five states in the Northeast registered oil spots (Ceará, Rio Grande do Norte, Paraíba Pernambuco, and Alagoas). 5) Three other states affected (Maranhão, Piauí, and Sergipe). 6) Including Bahia, all states of the Northeast region registered oil on the beaches. 7) First state in the Southeast region affected (São Mateus coast, Espírito Santo). 8) Oil reaches Rio de Janeiro, making it the 11th affected state. Source: IBAMA (2019a).

According to IBAMA reports, until February 2020, 11 states ( 9 at Northeast and 2 in the Southeast region) and 130 municipalities were affected. Overall, 1009 localities have registered oil contamination so far (Figure 2). The concept of locality used for mapping is restricted to an area of $1 \mathrm{~km}$ along the coast. Therefore, a beach with $10 \mathrm{~km}$ stretch of sand has 10 locations.

Regarding the affected fauna, so far, IBAMA is aware of 159 affected animals (being 112 dead and 47 alive but oiled - Figure 3). Overall, 2,814 baby turtles were preemptively captured in Bahia and Sergipe. At least 14 conservation units have already been polluted on the Northeastern coast, and more than 55 marine protected areas in the Tropical Atlantic have already been affected (IBAMA, 2019a; Soares et al., 2020).

Brazil has a coastline of $7,367 \mathrm{~km}$, of which around 4,000 km in length were affected by oil at some point during this period (Marinha do Brasil, 2019). Among the affected environmental areas considered sensitive are river mouths, water catchment points, mangroves, conservation units, and rhodolith beds (Nasri Sissini et al., 2020; Soares et al., 2020). The IBAMA informed that 5,300 tons of oil residue (oil and adhered sand) was collected and the institution applied $\mathrm{R} \$ 5,894,327.88$ to fund oil-related actions (IBAMA, 2019c). 


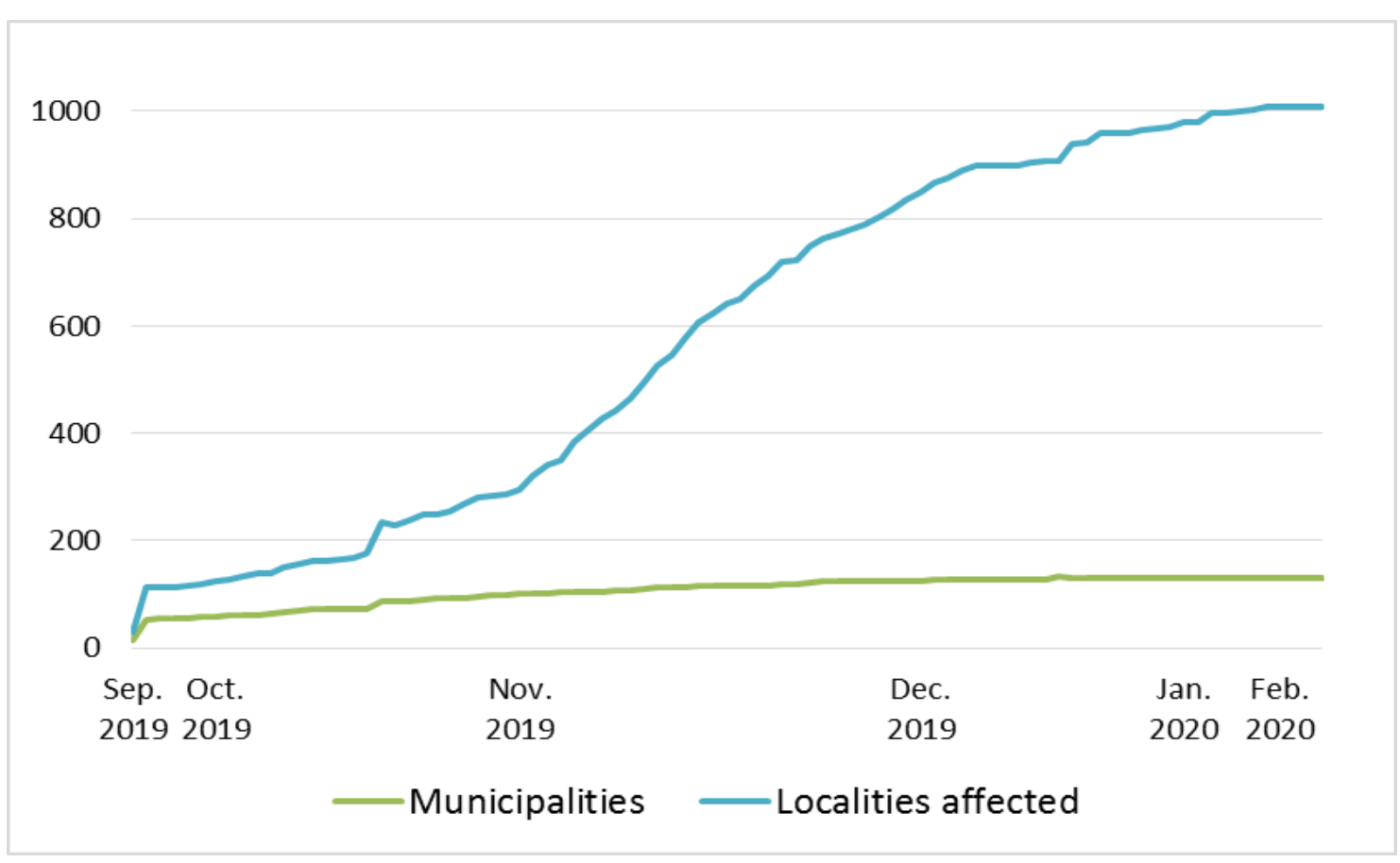

Figure 2. Temporal and quantitative progress of coastal areas affected by oil. The concept of locality is restricted to an area of $1 \mathrm{~km}$ along the coast. Data from August 30, 2019, to February 27, 2020. Source: IBAMA.

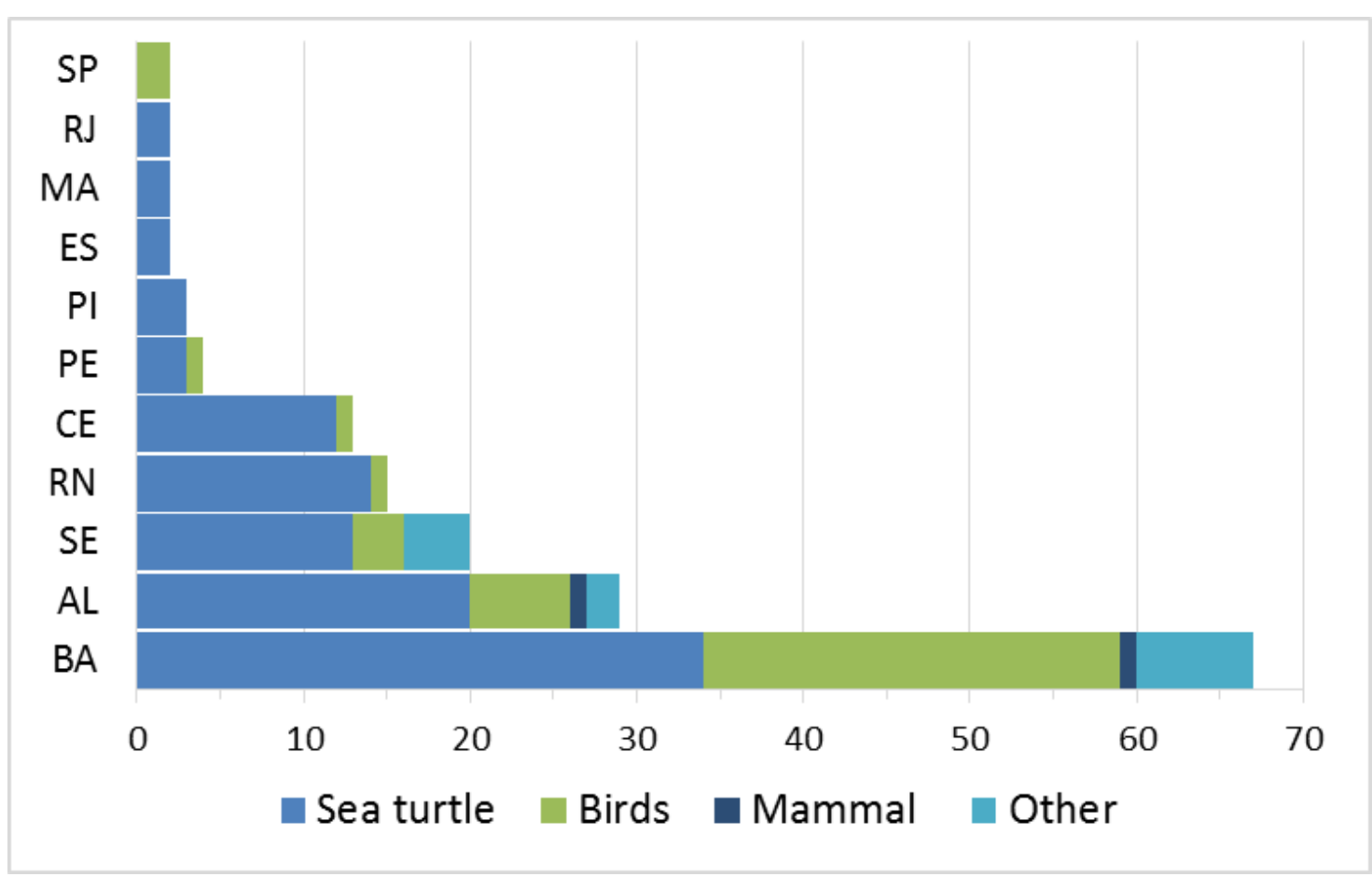

Figure 3. Absolute number of oiled animals per state, from which $70.4 \%$ were found dead. Records until February 12, 2020. Abbreviations refer to Brazilian States: SP - São Paulo, Rio de Janeiro - RJ, Maranhão - MA, Espírito Santo - ES, Piauí - PI, Pernambuco - PE, Ceará - CE, Rio Grande do Norte RN, Sergipe - SE, Alagoas - AL, Bahia - BA. Source: IBAMA. 
There is evidence that the government has been too slow to respond to the spill (Brum et al., 2020). A federal decree from 2013 (number 8127) states that when an oil spill occurs, IBAMA, ANP (National Petroleum Agency) and Navy have to monitor the situation and jointly decide whether to trigger the PNC (National Contingency Plan for Oil Pollution Incidents) protocol to be followed in large leaks. The PNC was officially formalized by Environment Minister Ricardo Salles just on October 11, 41 days after the first oil slicks emerged on the coast (Época Negócios, 2019). Even the "Operação Mácula" ("Blemish Operation") from Federal Police was started on November 1, two months after the first spots on the beaches.

\section{How much do we know about the oil source?}

Brazil does not have an operational monitoring system to systematical observations of oil spills at sea. According to the Environmental Letters website (news portal of the Satellite Image Analysis and Processing Laboratory - LAPIS), searching in satellite captures taken in July 19, 2019, by Sentinel-1A (European Space Agency) over the sea around the coast, has identified a big proportion oil stain of $25 \mathrm{~km}$ extension and 400 meters wide, at a distance of $26 \mathrm{~km}$ from the Brazilian Northeast coast (LAPIS, 2020).

Another even larger oil slick revealed by Sentinel-1A on July 24 was confirmed later by Acqua Modis and NOAA-20 Viirs satellite images. The pictures indicate that there was an oil spill on the North coast of the Northeast region, $40 \mathrm{~km}$ from the Rio Grande do Norte state coast. The spot detected was at least $85 \mathrm{~km}$ long and less than $1 \mathrm{~km}$ wide, which might be even bigger considering the lack of coverage of the satellite. Due to the density of the crude petroleum, it floats about $1.5 \mathrm{~m}$ below the surface, so it is not possible to precisely trace the source and location of pollution by satellite imagery or overflights (Figure 4). The oil is visible when it gets close to shore (Ascom - UFAL, 2019; Letras Ambientais, 2019a, 2019b).

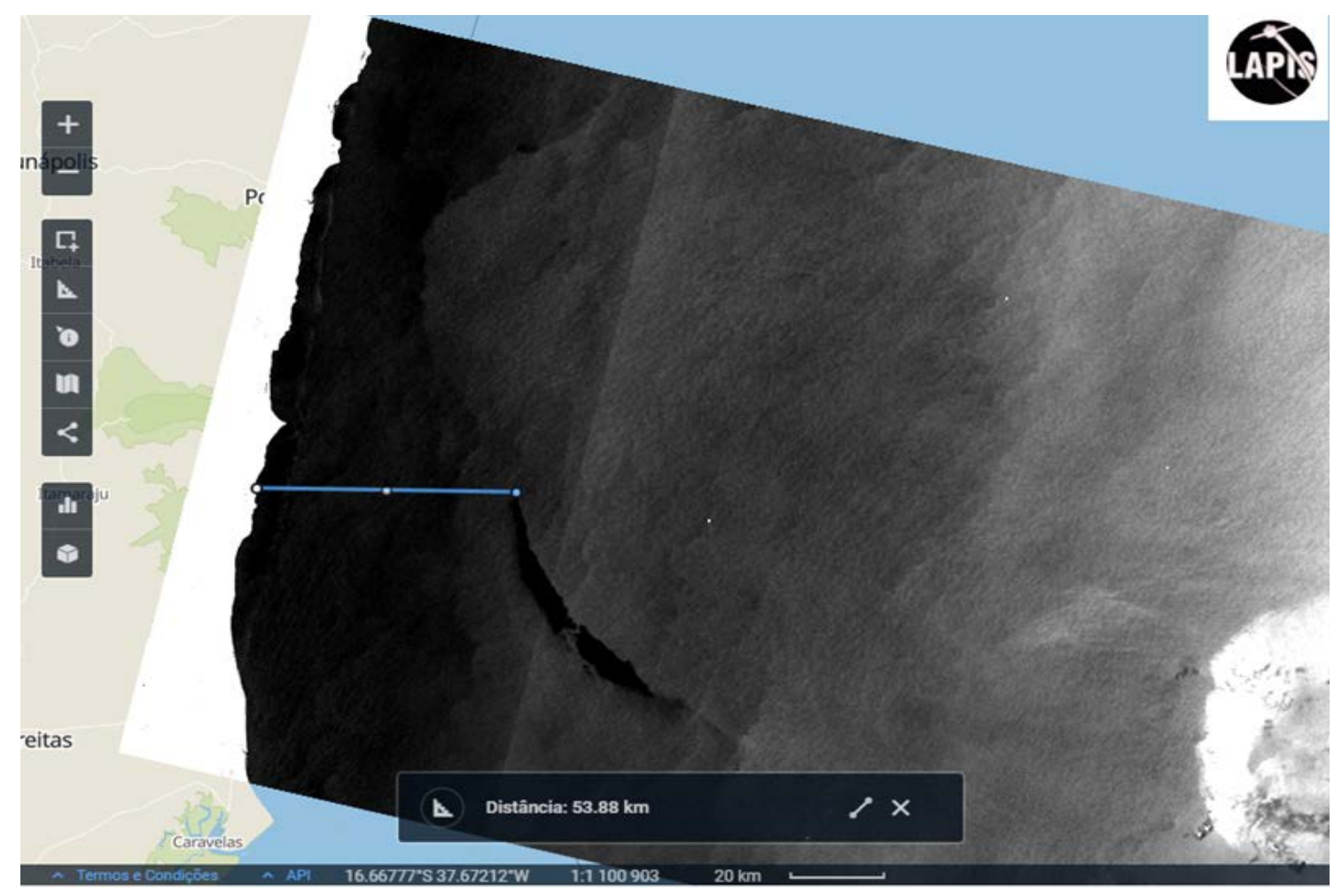

Figure 4. Sentinel-1A satellite records the oil slick near the Brazilian coast. Source: LAPIS (2020). 
Researchers from the Center for Excellence in Petroleum Geochemistry, Energy and Environment (LEPETRO - Federal University of Bahia) performed by their initiative, geochemical analyses that identify biomarkers (specific persistent molecules) that can indicate the petroleum source (referring to sedimentary environments and geological eras). They also performed fingerprint analysis by gas chromatography coupled with mass spectrometry and isotope analysis of crude oil samples collected in Sergipe and Bahia beaches. After analyzing the results, the researchers concluded that there is a strong correlation of the oil poured into the sea with one of the types produced in Venezuela. The specialists also state that none of the types of oil used in Brazil has the distribution of biomarkers and carbon isotope ratio present in the analysis. It is a work of forensic geochemistry, fundamental for the identification of characteristics and local production of oil. Petrobras analysis also corroborated these findings, and the hypothesis of the oil being from Venezuelan sources motivated the search for ships that left the country and passed through the Brazilian coast (Fioravanti, 2020; UFBA, 2019)

At the beginning of investigations, ships with commercial maritime routes close to the Brazilian coast were the main suspects of the Federal Police. According to analyzes, navy intelligence and satellite monitoring data made it possible to rule out the relationship between the trajectory of five Greek ships and the oil since cargo ships were in the suspect list of causing the accident. However, when the trajectories of the ships were correlated with satellite images, the occurrence was classified as "false positive" (Letras Ambientais, 2019c).

Even the hypothesis that the source of the leak could be occurring below the sea surface has been raised; however, as the chemical analyses have classified the oil as Venezuelan, it is unlikely that it originated in oil mines near the coast.

Considering the hypothesis of the oil source, investigators suspected that it was originated from a "ghost ship" or "dark ship" - irregular vessels carrying unidentified cargo, such as Venezuelan oil, whose trade is under the US embargo. One of these ships could have stocked up in Venezuela and later exchanged cargo with another ship. Thus, the country that bought Venezuelan oil would not suffer the sanctions imposed by the embargo. As the activity is illegal, this ship would not report any accidents, neither during charge change nor on a possible wreck. Still, months after the accident, the specific responsibility is uncertain. The navy conducts the investigations about the oil spill, and the Federal Police is the institution competent for investigating criminal liability. Under Brazilian law, it is essential to identify the responsible for the disaster once it must be in charge to pay for the damages - although some environmental effects occurred might be irreparable.

\section{Physical-chemical characteristics of the oil}

According to the authorities, the oil that reached the coast is heavy and highly weathered, which means it has undergone chemical, physical and biological processes over time; its main properties are high viscosity, high density, and low concentrations of volatile compounds. Based on these characteristics, it was supposed that the expected behaviors of oil in the marine environment would be: (i) persistence in the environment, (ii) density close to that of seawater and, therefore, being able to sink when encountering brackish waters, (iii) low levels of evaporation and (iv) low potential toxicity for marine organisms (although potential for physical suffocation of marine organisms that come into direct contact due to the high viscosity and density) (IBAMA, 2019c).

This statement from the environmental agencies is underestimated, besides not corroborated by the scientific community and literature when it comes to the possible effects on organisms. 
Crude petroleum oil has a biological origin when the remains of organisms are buried and subjected to high pressure and temperature for millions of years. Therefore, its composition depends directly on the source of the organic matter that originated it. Generally, it is composed of a complex mixture of hydrocarbons with over 1,000 compounds and molecular weight ranging from low (from $\mathrm{C} 1$ ) to high (more than C38). The main groups are saturated hydrocarbons (alkanes and cycloalkanes), aromatic, resins and asphaltenes (polycyclic compounds containing nitrogen, sulfur, and oxygen), and organometallic compounds (Committee On Oil in The Sea, 2003).

Official information from IBAMA stated that the oil found had a high degree of degradation, with a low content of volatile compounds (which are the ones with the lowest molecular weight). However, a research group from the Oceanographic Institute of the University of São Paulo (IO-USP) analyzed 11 oil samples from Pernambuco, Sergipe, and Alagoas and light hydrocarbons (mainly n-alkanes with less than 15 carbon atoms) were also found (Fioravanti, 2020).

Once the spill was originated offshore, the oil was submitted to a variety of processes for an extended period, mainly due to open sea conditions (e.g. constant agitation, solar incidence, etc.). The weathering process can remove part of low molecular weight hydrocarbons from oil-water mixtures through evaporation, subsequently producing oil slicks with proportionally higher molecular weight and low solubility PAHs (Carls and Meador, 2009). Part of these compounds in contact with water creates a solution named water-accommodated fraction (WAF) of oil.

The WAF is the aqueous phase after fresh or saline water is mixed with crude oils for a period. This fraction contains high amounts of oil droplets and also water-soluble compounds derived from oil. Common physical-chemical properties rule the ability of these chemical compounds to partition into the aqueous phase (mainly polarity, measured by Octanol-water partition coefficient - $\mathrm{K}_{\mathrm{ow}}$ ) (Liu and Kujawinski, 2015).

Among the High Molecular Weight (HMW) compounds that can be present in the WAF, attention must be given to Polycyclic Aromatic Hydrocarbons (PAHs), which are formed of two or more fused benzene rings. Although they are minor components of crude oil, they represent by far the most critical HMW compounds in terms of chronic environmental impacts (Abrajano et al., 2003).

When in contact with seawater, it is also possible to form the Water-soluble Fraction (WSF), which is, in fact, a subset of WAF but without the oil droplets and containing only truly soluble compounds (Liu and Kujawinski, 2015). Galvan (2015) analyzed the composition of WSF from crude oil and found concentrations of 316,40 $\mu \mathrm{g} \mathrm{l}^{-1}$ of benzene, $23,30 \mathrm{~g} \mathrm{l}^{-1}$ of ethylbenzene, $211,80 \mathrm{~g} \mathrm{l}^{-1}$ of toluene and 124,2 $\mathrm{mg} \mathrm{l}^{-1}$ of xylene. PAHs analysis pointed to concentrations ranging from $\sim 3-15 \mu \mathrm{g} \mathrm{l}^{-1}$ (for anthracene, benzo[b]fluoranthene, benzo[g,h,i]perylene, chrysene, phenanthrene, fluoranthene, naphthalene, and pyrene) until $300 \mu \mathrm{g} \mathrm{l}^{-1}$ for benz[a]anthracene (Galvan, 2015).

$\mathrm{Xu}$ et al. (2016) showed that physical and chemical processes (such as ultraviolet light) could change the structure of the oil components, which can generate degradation by-products with even higher toxicity (XU et al., 2016). The authors of this study simulated the WAF of an un-weathered oil (source oil) compared to weathered oil from the DWH spill (slick oil). Analyses performed with gas chromatography coupled with mass spectrometry showed that the WAF from the source oil was comprised predominantly of 2-ring PAHs (72\%), followed by 3-ring PAHs (27\%), mainly represented by the naphthalenes and phenanthrenes/anthracenes, respectively. By contrast, the WAF from the slick oil was characterized by the loss of 2-ring PAHs (5\%) and enrichment of 3-ring (69\%) and 4-ring (25\%) PAHs (Xu et al., 2016). 
Similarly, Magnuson et al. (2018) analyzed the high-energy water accommodated fractions (HEWAFs) of weathered slick oil from the DWH spill. The prepared HEWAFs were comprised primarily of 3-ring PAHs (75\%), followed by 4-ring PAHs (18\%), with the majority represented as C1- and C2 phenanthrenes/anthracenes (Magnuson et al., 2018).

Even if the authorities declared that the oil spilled in the Northeast has low toxicity, attention should be paid to the toxic potential of these xenobiotics, and further studies of their toxic effects must be developed.

\section{Effects of oil exposition}

During cleaning activities on the beaches contaminated with oil stains, dozens of volunteers reported cases of intoxication (Dantas and Manzano, 2019; Pitombo and Valadares, 2019). When exposed to the sun, the oil begins to vaporize and release toxic gases, and these dangerous substances can affect the skin and lungs when inhaled, which is the main route of absorption in humans. Also, it might cause dermatitis, redness, swelling, respiratory symptoms, headache, nausea, abdominal pain, vomiting, and diarrhea. The symptoms vary according to the time of exposure and the concentration of the compounds that come into contact. Three volatile petroleum compounds (benzene, toluene, and xylene) are hazardous to long-term health, in addition to the high carcinogenic potential that can cause diseases in the central nervous system of different organisms (IARC, 2020).

If a short exposure time was able to trigger such effects on humans, it is possible to infer and predict the harm it caused to the aquatic wildlife that has been exposed during the whole incident and for a more extended period. The toxicity of water-soluble components derived from crude and refined oils to marine organisms are recognized as early as the 1970s (Anderson et al., 1974; Griffin and Calder, 1977).

Most of the chemical compounds that compose the oil are lipophilic substances and, thus, they are quickly dissolved and transported by the lipoproteins of the cell membranes. The absorption rate depends on the compound and the route of entry. In general, they are widely distributed throughout the body and can be found in any organ or tissue, especially those rich in lipids and the gastrointestinal tract (Nardocci, 2010).

Controlled tests with the fish Astyanax serratus demonstrated that the Soluble Fraction of Petroleum (SFP) was not lethal to these organisms. Still, it was observed an increase in DNA damage in blood cells, gills, anterior kidney, brain, and reproductive cells, in addition to the induction of micronuclei and an increase in the hepatogonadossomatic index (Galvan, 2015). The high occurrence of DNA breaks may be related to the presence of Benzene, Toluene, Ethylbenzene, and Xylene (BTEX), which similarly have been reported on Amazonian electric fish Apteronotus bonapartii (Bücker et al., 2012).

PAHs present in crude oil have been shown to cause the dysregulation of important genes in eye development and function, as well as morphological abnormalities of the eye, which represent a threat to the animal survival and maintenance in the habitats considering the importance of vision (Xu et al., 2018). Likewise, in terms of fitness, Mager et al. (2014) have shown that brief exposure of WAF from the DWH spill to Coryphaena hippurus as juveniles or as embryos/larvae reduces their swimming performance and increases the incidence of pericardial and yolk sac edema (Mager et al., 2014).

According to Peterson et al. (2003), in 1989, during the Exxon Valdez oil spill in Alaska, the prediction of oil risk to fishes was mainly based on testing acute toxicity in short-term (4-day) laboratory exposures to the WSF dominated by 1- and 2-ringed aromatic hydrocarbons. After the spill, fish embryos and larvae were chronically exposed in the laboratory to partially weathered oil in dispersed forms that accelerate the dissolution of 3-, 4-, and 5-ringed hydrocarbons. The findings showed that these multiringed PAHs from partially weathered oil at concentrations as low as $1 \mathrm{ppb}$ are toxic to 
pink salmon eggs exposed for the months of development and to herring eggs exposed for 16 days. Chronic exposures for years after the spill to oil persisting in sedimentary refuges were evident from biomarkers in fish, sea otters, and seaducks intimately associated with sediments for egg-laying or foraging.

Research showed that even weathered oil in the Gulf of Mexico might threaten the development of native species. Using embryos and larvae of Coryphaena hippurus, it was found significant changes in gene expression related to critical functions in the exposed embryos and larvae. This research also pointed to the toxic potential for interferences in the heart and eye development, and neurological function of these organisms (Xu et al., 2016).

In the same perspective, another study was conducted on miRNA-mRNA interactions in fish larvae exposed to different concentrations of WAF of both weathered and non-weathered DWH oils. The results showed four dose-dependent miRNA biomarkers consistent with target genes involved in morphological, physiological, behavioral changes, cardiovascular development, visual and nervous system, and associated toxicity pathways (Xu et al., 2018).

Previously, it was assumed that impacts to populations derive almost exclusively from acute mortality. However, in the Alaskan coastal ecosystem, unexpected persistence of toxic subsurface oil and chronic exposures, even at sublethal levels, have continued to affect wildlife. These findings contravened a longstanding paradigm wherein lower molecular weight and more volatile 2-ring PAHs have a greater responsibility to drive crude oil toxicity (Peterson et al., 2003).

A review of the accumulated knowledge about ecosystem response to oil spills shows that current practices for assessing ecological risks of oil in the oceans should be changed. Nevertheless, these uncertainties do little to diminish the general conclusions. In essence, oil persisted beyond a decade in surprising amounts, and toxic forms were sufficiently bioavailable to induce chronic biological exposures and had long-term impacts at the population level. Three significant pathways of induction of the long-term effects emerge: (i) chronic persistence of oil, biological exposures, and population impacts to species closely associated with shallow sediments; (ii) delayed population impacts of sublethal doses compromising health, growth, and reproduction; and (iii) indirect effects of trophic and interaction cascades, all of which transmit impacts well beyond the acutephase mortality (Peterson et al., 2003).

\section{Final considerations}

Since the beginning of September 2019, Brazil has been sensitized and united in the fight against the environmental crime that affects the coast. The occurrence is unprecedented in Brazilian history due to its geographical extension and duration over time. In view of the announcement of the demobilization plan and a considerable decrease in media coverage, it is necessary to maintain this issue as a central theme in the Brazilian debate. It is essential to recap all the main events from the first spots registered until the ending of cleaning and monitoring activities. Also, it is especially relevant to inform clearly and responsibly that several areas will remain polluted and littering toxic contaminants for many years. Considering natural degradation as the only option for sensitive environments without keeping in mind the inherent risks does not seem like a prudent decision.

The negligent reaction of public authorities and the precariousness of the environmental agencies, which have limited resources and personnel, open up the fragility that this agenda is treated. The ecological damage is evident. Moreover, it is essential to handle the case as a public health issue once the people are contaminated, and the food 
chain transfer of hydrocarbons and other chemical components is major in coastal populations that have a source of food and income at sea.

Brazil faces a significant challenge concerning environmental preservation. In the case of oil accidents, we could draw on previous worldwide experiences to get around this major problem by taking the most efficient measures that make it possible to restore the health of the affected ecosystems. At least, since there are already studies in the scientific literature confirming the potential long-term risks, it is not prudent to omit such effects disseminating incomplete information to the population. It is necessary to recognize that there are long-term effects, and the remaining oil is not inert. Exposed organisms will truly be affected for an extended period of time, and we will not know precisely the dimensions if we do not point it as an effectively relevant problem.

This work sheds light on a multidisciplinary theme of extreme relevance because, in addition to environmental preservation, it deals with the social relations of communities and territories, which goes far beyond the geographical concept, indeed understood here as the space over which forms of political organization are consolidated by local communities. Finally, precautionary and reparatory actions must be planned so that the global goals for sustainable development, settled by the United Nations, must be conquered, especially those concerning clean water and aquatic life preservation.

\section{Conflicts of interest}

The author declares that have no conflict of interests.

\section{References}

Abrajano, T. A., Jr.; Yan, B.; Song, J.; Bopp, R. High-molecular-weight petrogenic and pyrogenic hydrocarbons in aquatic environments. In: Holland, H. D.; Turekian, K. K. Treatise on Geochemistry. New York: Elsevier Science, 2003. v. 9. p. 475-509. https://doi.org/10.1016/B0-08-043751-6/09055-1

Anderson, J. W.; Neff, J. M.; Cox, B. A.; Tatem, H. E.; Hightower, G. M. Characteristics of dispersions and water-soluble extracts of crude and refined oils and their toxicity to estuarine crustaceans and fish. Marine Biology, v. 27, p.75-88, 1974. https://doi.org/10.1007/BF00394763

Ascom - UFAL. Lapis alerta que mais um satélite detectou grande vazamento de óleo. Universidade Federal de Alagoas. 2019. Available from: $<$ https://ufal.br/ufal/noticias/2019/11/lapis-alerta-que-mais-um-satelite-detectougrande-vazamento-de-oleo>. Accessed on: Dec. 2, 2019.

BBC News. Brazil oil spill: Where has it come from? BBC News. 2019. Available from: <https://www.bbc.com/news/world-latin-america-50223106>. Accessed on: Dec. 15, 2019.

Bücker, A.; Carvalho, M. S.; Conceição, M. B.; Alves-Gomes, J. A. Micronucleus test and comet assay in erythrocytes of the Amazonian electric fish Apteronotus bonapartii exposed to benzene. Journal of the Brazilian Society of Ecotoxicology, v. 7, p. 65-73, 2012. https://doi.org/10.5132/jbse.2012.01.010

Carls, M. G.; Meador, J. P. A perspective on the toxicity of petrogenic pahs to developing fish embryos related to environmental chemistry. Human and Ecological Risk Assessment: $\begin{array}{lllll}\text { An International Journal, } & \text { v. 15, } & \text { no. 6, } & \text { p. 1084-1098, }\end{array}$ https://doi.org/10.1080/10807030903304708 
Committee on Oil in the Sea. Oil in the sea III: Inputs, fates, and effects. Washington, DC: The National Academies Press, 2003.

Costa, C.; Gomes, L. A batalha de Cubatão contra a poluição atmosférica. BBC News, 2017. Available from: <https://www.bbc.com/portuguese/media-39236610>. Accessed on: Jan. 13, 2020.

Dantas, C.; Manzano, F. 70 casos de intoxicação são notificados por 3 estados do Nordeste após contato com petróleo. Portal G1 Notícias, 2019. Available from: <https://g1.globo.com/natureza/desastre-ambiental-petroleo-

praias/noticia/2019/11/08/70-casos-de-intoxicacao-sao-notificados-por-3-estados-donordeste-apos-contato-com-petroleo.ghtml>. Accessed on: Dec. 15, 2019.

Dantas, C.; Oliveira, E.; Manzano, F., Figueiredo, P. Óleo no Nordeste: veja a evolução das manchas e quando ocorreu o pico do desastre que completa 2 meses. Portal G1, 2019. Available from: <https://g1.globo.com/natureza/desastre-ambiental-petroleopraias/noticia/2019/11/08/70-casos-de-intoxicacao-sao-notificados-por-3-estados-donordeste-apos-contato-com-petroleo.ghtml>. Accessed on: Dec. 15, 2019.

Época Negócios. Salles acionou plano de contingência no Nordeste 41 dias após desastre, diz documento. Época Negócios, 2019. Available from: <https://epocanegocios.globo.com/Brasil/noticia/2019/10/salles-acionou-plano-decontingencia-no-nordeste-41-dias-apos-desastre-diz-documento.html>. Accessed on: Dec. $15,2019)$.

Fioravanti, C. Os caminhos da mancha. Pesquisa FAPESP, 2019. Available from: <https://revistapesquisa.fapesp.br/2019/12/03/os-caminhos-da-mancha/>. Accessed on: Mar. 10, 2020.

Galvan, G. L. Efeitos ecotoxicológicos da fração solúvel do petróleo e gasolina: integrando relevantes organismos e biomarcadores. Curitiba: Universidade Federal do Paraná, 2015. (Thesis).

Galvan, G. L.; Lirola, J. R.; Felisbino, K.; Vicari, T.; Yamamoto, C. I.; Cestari, M. M. Genetic and hematologic endpoints in Astyanax altiparanae (Characidae) after exposure and recovery to water-soluble fraction of gasoline (WSFG). Bulletin of Environmental Contamination and Toxicology, v. 97, p. 63-70, 2016. https://doi.org/10.1007/s00128-016-1816-5

Gonçalves, D. P. Principais desastres ambientais no Brasil e no mundo. Jornal da Unicamp, 2017. Available from: <https://www.unicamp.br/unicamp/ju/noticias/ 2017/12/01/principais-desastres-ambientais-no-brasil-e-no-mundo $>$. Accessed on: Jan. $15,2020$.

Griffin, L. F.; Calder, J. A. Toxic effect of water-soluble fractions of crude, refined, and weathered oils on the growth of a marine bacterium. Applied and Environmental Microbiology, v. 33, no. 5, p. 1092-1096, 1977.

IBAMA. Manchas de óleo - litoral brasileiro. 2019a. Available from: <http://www.ibama.gov.br/manchasdeoleo>. Accessed on: Dec. 15, 2019.

IBAMA. Portal - Mancha no Litoral. 2019b. Available from: <https://brasil.gov.br/ manchanolitoral/>. Accessed on: Dec. 15, 2019.

IBAMA. Cartilha informativa sobre a trajetória do acidente/Desmobilização. 2019c. Available from: <http://www.ibama.gov.br/manchasdeoleo-desmobilizacao>. Accessed on: Dec. 15, 2019. 
IARC - International Agency for Research on Cancer. IARC monographs on the identification of carcinogenic hazards to humans. 2020. Available from: <https://monographs.iarc.fr/agents-classified-by-the-iarc/>. Accessed on: Mar. 10, 2020.

LAPIS - Laboratório de Análise e Processamento de Imagens de Satélites. 2020. Available from: <http://lapismet.com.br/>. Accessed on: Mar. 10, 2020.

Letras Ambientais. Novas pistas podem esclarecer definitivamente origem do óleo no Nordeste. 2019a. Available from: <https://letrasambientais.org.br/posts/novas-pistaspodem-esclarecer-definitivamente-origem-do-oleo-no-nordeste->. Accessed on: Dec. 15, 2019.

Letras Ambientais. Mais um satélite detecta grande vazamento de óleo próximo ao RN. 2019b. Available from: <https://letrasambientais.org.br/posts/mais-um-satelite-detectagrande-vazamento-de-oleo-proximo-ao-rn>. Accessed on: Dec. 15, 2019.

Letras Ambientais. Por que os 5 navios gregos não poluiram o litoral do nordeste? 2019c. Available from: <https://letrasambientais.org.br/posts/por-que-os-5-navios-gregos-naopoluiram-o-litoral-do-nordeste->. Accessed on: Dec, 15, 2019.

Liu, Y.; Kujawinski, E. B. Chemical composition and potential environmental impacts of water-soluble polar crude oil components inferred from esi FT-ICR MS. PLoS ONE, v. 10, no. 9, e0136376, 2015. https://doi.org/10.1371/journal.pone.0136376

Madeiro, C. Óleo no Nordeste: o que se sabe até agora sobre a contaminação das praias. Notícias UOL, 2019. Available from: <https://noticias.uol.com.br/meioambiente/ultimas-noticias/redacao/2019/10/22/oleo-no-nordeste-o-que-se-sabe-ateagora-sobre-a-contaminacao-das-praias.htm>. Accessed on: Dec. 15, 2019.

Mager, E. M.; Esbaugh, A. J.; Stieglitz, J. D.; Hoenig, R.; Bodinier, C.; Incardona, J. P.; Scholz, N. L.; Benetti, D. D.; Grosell, M. Acute embryonic or juvenile exposure to deepwater horizon crude oil impairs the swimming performance of mahi-mahi (Coryphaena hippurus). Environmental Science \& Technology, v. 48, no. 12, p.7053-7061, 2014. https://doi.org/10.1021/es501628k

Magnuson, J. T.; Khursigara, A. J., Allmon, E. B., Esbaugh, A. J., Roberts, A. P. Effects of Deepwater Horizon crude oil on ocular development in two estuarine fish species, red drum (Sciaenops ocellatus) and sheepshead minnow (Cyprinodon variegatus). Ecotoxicology and Environmental Safety, v.166, p.186-191, 2018. https://doi.org/10.1016/j.ecoenv.2018.09.087

Marinha do Brasil. Manchas de Óleo. 2019. Available from: <https://www.marinha.mil.br/manchasdeoleo>. Accessed on: Mar. 10, 2020.

Nardocci, A. C. Avaliação probabilística de riscos da exposição aos hidrocarbonetos policíclicos aromáticos (HPAs) para a população da Cidade de São Paulo. São Paulo: Universidade de São Paulo, 2010. (Thesis).

Nasri Sissini, M.; Berchez, F.; Hall-Spencer, J.; Ghilardi-Lopes, N.; Carvalho, V. F.; Schubert, N.; Koerich, G.; Diaz-Pulido, G.; Silva, J.; Serrão, E.; Assis, J.; Santos, R.; Floeter, S. R.; Rörig, L.; Barufi, J. B.; Bernardino, A. F.; Francini-Filho, R.; Turra, A.; Hofmann, L. C.; Aguirre, J.; Le Gall, L.; Peña, V.; Nash, M. C.; Rossi, S.; Soares, M.; Pereira-Filho, G.; Tâmega, F.; Horta, P. A. Brazil oil spill response: Protect rhodolith beds. Science, v. 367, p. 156-156, 2020. https://doi.org/10.1126/science.aba2582

Peterson, C. H.; Rice, S. D.; Short, J. W.; Esler, D.; Bodkin, J. L.; Ballachey, B. E.; Irons, D. B.; Long-term ecosystem response to the Exxon Valdez Oil Spill. Science, v. 302, p. 20822086, 2003. https://doi.org/10.1126/science.1084282 
Pitombo, J. P.; Valadares, J. Voluntários relatam intoxicação após manuseio de óleo nas praias. Folha de S. Paulo, 2019. Available from: <https://www1.folha.uol.com.br/ ambiente/2019/10/voluntarios-relatam-intoxicacao-apos-manuseio-de-oleo-naspraias.shtml>. Accessed on: Mar. 10, 2020.

Secretaria de Vigilância em Saúde. Boletim Epidemiológico - Vigilância em Saúde: monitoramento das manchas de óleo no litoral do Nordeste. Ministério da Saúde. 2019. Available from: <https://portalarquivos2.saude.gov.br/images/pdf/2019/outubro/31/ Boletim-epidemiologico-SVS-32.pdf>. Accessed on: Dec. 2, 2019.

Sindipetro-LP. Uma tragédia em muitas lições: 35 anos do incêndio da Vila Socó. 2019. Available from: <http://www.sindipetrolp.org.br/noticias/26555/uma-tragedia-e-muitaslicoes-35-anos-do-incendio-da-vila-soco>. Accessed on: Dec. 2, 2019.

Soares, M. O.; Teixeira, C. E. P.; Bezerra, L. E. A.; Paiva, S. V.; Tavares, T. C. L.; Garcia, T. M.; Araújo, J. T.; Campos, C. C.; Ferreira, S. M. C.; Matthews-Cascon, H.; Frota, A.; Mont'Alverne, T. C. F.; Silva, S. T.; Rabelo, E. F.; Barroso, C. X.; Freitas, J. E. P.; Melo Júnior, M.; Campelo, R. P. S.; Santana, C. S.; Carneiro, P. B. M.; Meirelles, A. J.; Santos, B. A.; Oliveira, A. H. B.; Horta, P.; Cavalcante, R. M. Oil spill in South Atlantic (Brazil): Environmental and governmental disaster. Marine Policy, v. 115, 2020. https://doi.org/10.1016/j.marpol.2020.103879

The Guardian. Brazil blames devastating oil spill on Greek-flagged tanker. 2019. Available from: <https://www.theguardian.com/world/2019/nov/01/brazil-blames-oil-spillgreek-flagged-tanker-venezuelan-crude>. Accessed on: Dec. 2, 2019.

UFBA. Análises do Lepetro/Igeo indicam correlação entre óleo encontrado nas praias do Nordeste e petróleo venezuelano. Lepetro-UFBA, 2019. Available from: $<$ https://ufba.br/ufba_em_pauta/analises-do-lepetroigeo-indicam-correlacao-entre-oleoencontrado-nas-praias-do>. Accessed on: Dec. 2, 2019.

US National Academy of Science. Behavior and fate of oil - oil in the Sea III: Inputs, fates, and effects. The National Academies Press, Washington, DC, 2004.

Xu, E. G.; Mager, E. M.; Grosell, M.; Pasparakis, C.; Schlenker, L. S.; Stieglitz, J. D.; Benetti, D.; Hazard, E. S.; Courtney, S. M.; Diamante, G.; Freitas, J.; Hardiman, G.; Schlenk, D. Time- and oil-dependent transcriptomic and physiological responses to deepwater horizon oil in mahi-mahi (Coryphaena hippurus) embryos and larvae. Environmental Science \& Technology, v. 50, no. 14, p. 7842-7851, 2016. https://doi.org/10.1021/acs.est.6b02205

Xu, E. G.; Magnuson, J. T.; Diamante, G.; Mager, E.; Pasparakis, C.; Grosell, M.; Roberts, A. P.; Schlenk, D. Changes in microRNA-mRNA signatures agree with morphological, physiological, and behavioral changes in larval mahi-mahi treated with deepwater horizon oil. Environmental Science \& Technology, v. 52, no. 22, p.13501-13510, 2018. https://doi.org/10.1021/acs.est.8b04169

License information: This is an open-access article distributed under the terms of the Creative Commons Attribution License, which permits unrestricted use, distribution, and reproduction in any medium, provided the original work is properly cited. 